\author{
W. Julian Korab-Karpowicz \\ University of Opole, Poland \\ ORCID: 0000-0003-0735-0620 \\ e-mail:wjkk@trinity-oxford.org
}

\title{
Evolutionity - A New Age of Humanity: On the Concept of Human Evolution by Hoene-Wroński
}

DOI: http://dx.doi.org/10.12775/RF.2018.032

One of the most powerful and comprehensive philosophical ideas is that of human evolution. It has been discussed by Herbert Spencer, Teilhard de Chardin, Julian Huxley ${ }^{1}$ and other thinkers, and is linked to the evolutionary view of reality. Before these thinkers, because already at the beginning of the nineteenth century, it was examined by the Polish philosopher and mathematician, Józef Hoene-Wroński. ${ }^{2}$

1 See Robert L. Carneiro, ed., The Evolution of Society: Selections from Herbert Spencer's Principles of Sociology (Chicago: The University of Chicago Press, 1967); Julian Huxley, Evolutionary Humanism (New York: Prometheus, 1992); Teilhard de Chardin, The Phenomenon of Man (New York: Herper, 2008).

2 Józef Maria Hoene-Wroński (in French Josef Hoëné-Wronski) was born on 23 August 1776 in Wolsztyn, Poland and died on 9 August 1853 in Neulilly-sur-Seine in France. He was the oldest son of Czech architect Antoni Hoëné and changed his name to Wroński when at the age of sixteen he escaped his family home to attend a military academy. He became an artillery officer and soon had proven his talent. In 1794 he commanded an artillery unit in the Kosciuszko uprising against Russia and was decorated by Kosciuszko himself. As the uprising fell, he was taken prisoner by the Russians, who, while recognizing his abilities, invited him to serve in the Russian army. Wronski accepted and was promoted to the rank of lieutenant colonel. Yet he resigned from the Russian service in 1798, moved to Germany and then to France, where for a brief period he was enlisted in the Polish Legion in Marseille - a military unit that served with the French Napoleonic Army. There he also began his scientific and scholarly work, and conceived the idea of a great philosophical system. In 1810 
In this article I present the concept of human evolution by HoeneWroński. I believe that his ideas are still an unexplored resource which can lead us to the better understanding of the evolution of humanity and of our destiny. I follow closely his discussion of human evolution and describe its seven stages. Further, I argue that the case of human evolution is strongly supported by new scientific theories, especially by quantum theory and the novel perspectives that it opens for humankind. I end my article with the conclusion that the insights on human evolution derived from the Hoene-Wroński's writings and from new scientific theories can guide us to the new politics based on the awareness of human identity that can overcome old divisions among humankind and conflicts derived from them. Ultimately, they can initiate evolutionity the new evolutionary epoch, which will replace modernity and postmodernity.

\section{On Human Evolution}

Evolution can be defined as the process by which reality, or what-exists, emerges in stages in which novelty, variety and sophistication are generated. The secular evolutionist Julian Huxley divides the evolutionary process into its basic cosmological, biological, cultural or human phases. ${ }^{3}$ He also proposes to replace traditional religions with his new religion of humanism. However, the evolutionary view of reality does not have to be interpreted as challenging the religious creation view, namely, that the world was created by God. ${ }^{4}$ Evolution is a creative process. Divine creation can proceed by the way of evolution, as illustrated by the book of Genesis, in which it is said that the world did not come about immediately, but only gradually, and the symbolism of its gradual formation is expressed in the form of seven days of creation. Whether reality is created or originates by itself or has always existed, science cannot answer. What is existence? Why does the world exist? How did it come about? Was it created or did it originate by itself? What was there before? These

he married Victory Sarrazin de Montferrier, from a French aristocratic family, and remained in France for the rest of his life. With the objective to completely reform philosophy as well as mathematics, astronomy and technology, he published over one hundred works and left many in manuscript form. His contemporaries were unprepared to accept the novelty of his ideas, and his opposition to materialism and determinism. During his lifetime nearly all his work was dismissed as nonsense. He wrote exclusively in French.

3 Huxley, Evolutionary Humanism, 29-33.

4 This view that the quarrel between evolutionists and creationists is unfounded is expressed in Michal Heller, Nowa fizyka i nowa teologia (Kraków: Copernicus Center Press, 2014), 156. 
questions belong the Mystery of Existence and transcend the limits of human understanding. They are philosophical or theological questions that fall out of the scientific domain.

It is characteristic of human beings that we can subject our lives to self-reflection, create culture and purposively change our environment. Human evolution is still to a degree biological, depending on right gene selection and proper nutrition; but primarily it is cultural, based on transmission of knowledge and values. We are no longer subjected to the automatic agency of natural selection. We are not mechanically determined in any way. The character of our future existence largely depends on our consciously and purposely developed material, moral, and intellectual environment: on our prosperity, education, beliefs, ideals, and traditions. Variations in them are reflected in individual, ethnic, national, class and religious differences. Just as at the beginning of the biological phase of evolution, living organisms are very simple and require a long time to develop, during which they develop more complex functions, so also human beings, though the most perfect of all creatures, are still unfinished beings and develop from primitivism to perfection. Therefore, identifying people with egoism or with a permanent state of sinfulness is an intellectual error. Such as view does not take into account that human beings, like everything in the universe, are subject to evolution, and thus can develop morally and intellectually. Their self-creativity, or the ability to consciously shape their lives, develop with the progress of civilization, an integral element of which is moral development.

\section{The Initial States of Human Evolution}

Josef Hoene-Wroński described human evolution in seven stages, ${ }^{5}$ which in my contemporary reading are as follows. First, as humanity emerges from barbarity, where there is no established moral order, the initial stage of human evolution comes with the great codes of law. ${ }^{6}$ These are the laws of Hammurabi in Babylon, of Moses in Israel, of Manu in India, and of other lawgivers in places where early civilizations started to de-

5 See Josef M. Hoene-Wroński, Messianisme, Union Finale de La Philosophie Et de La Religion Constituant La Philosophie Absolue (Maurepass: Hachette Livre-Bnf, 2013); Josef M. Hoene-Wroński, Propedeutique Messianique: Elements de La Philosophie Absolue (Maurepass: Hachette Livre-Bnf, 2015); Josef M. Hoene-Wroński, Le Sphinx (Charleston, NC: Nabu Press, 2011).

6 Since there no English translation of Hoene-Wroński's main work on human evolution, which is Messianisme, Union Finale de La Philosophie Et de La Religion Constituant La Philosophie Absolue, as references I will use its Polish edition: Józef HoeneWroński, Metapolityka, transl. from French by J. Jankowski (Warszawa: GebethnerWolff, 1923). See Hoene-Wroński, Metapolityka, 70-71 and 116-118. 
velop. In the early stages of their development, primitive human beings could understand a moral imperative that opposed their impulses and bodily tendencies only as a commandment from supernatural beings or from God. The task of these divine-inspired legal codes was to provide human beings with a basic moral guidance. Exciting the fear of punishment, they tried to inspire obedience by acting on the threat of external force alone. ${ }^{7}$ The second stage of evolution takes place in ancient Greece and Rome. Not only is political freedom then discovered and practically implemented in the Athenian polis, and later in the Roman republic, but also, with the beginning of philosophy, there is a development of free rational inquiry and of ethical thinking based on virtue. The form of government, based on established laws, is to guarantee citizens individual independence, and henceforth excludes physical dependence among them, other than that resulting from their duties as citizens. ${ }^{8}$ The Greek and Roman ideas of virtuous conduct and of natural law then developed refer to our inner moral qualities, and not to an external threat.

Morality is further internalized in the third stage, which begins with Christianity. Whereas earlier religions revealed moral commandments, Christianity reveals the Word, a new teaching of God and the idea of redemption from moral decline and the human perfection contained in it. ${ }^{9}$ Because of Christianity, human beings learn higher goals in life than merely material or political. They discover a higher moral order than justice: love. We cannot be forced to love others but can only internalize love in ourselves. The essential Christian ethical teachings based on the commandment "Love your neighbor as yourself" are thus founded on our inner discipline and moral self-transformation. They have a universal, all-embracing ethical character. ${ }^{10}$ They introduce into our lives an element of spiritual freedom, which has a creative and transforming influence on both our personal inner experiences and on the historical destiny of our societies. They produce an essential social dynamism, which introduces the notion of the changing of the world for better into the Western ideal.

7 See Steven Pinker, The Better Angels of Our Nature: Why Violence Has Declined (New York: Penguin, 2011). Pinker describes a "pacification process" through which tribal warfare, feuding and brigandry were brought under control by harsh laws, to be followed by a "civilizing process."

8 Hoene-Wroński, Metapolityka, 81-82 and 118-121.

9 Ibidem, 121-122.

10 Christianity reinforces the universal character of ethics that is already developing in Greek and Roman moral philosophy, and for which a strong evidence can be found, for example, in De Officiis of Cicero. It rejects a double morality - one towards those who belong to our community and another towards outsiders - and affirms common ethics and the same rights for all humans. 
The main weakness of religions is that they sometimes forget about their spiritual origin, acquire a political character and, like secular ideologies, accept rigid, dogmatic interpretations of reality. This is not a coincidence, but rather a result of the activities of some people, who, often elevated to high positions in the religious hierarchy, are unable to grasp the spiritual message of their own religions. Consequently, they introduce "confusion in its commands and dogmas." ${ }^{11}$ Dogmatism is a destructive force because it monopolizes truth. By assuming that certain ideas are undoubtedly true, the dogmatists or ideologues try to persuade others to accept them uncritically and attempt to kill any independent thinking, and thus stop the process of human intellectual development. Here is the origin of some heresies that weakened and divided Christianity, the great split of the Church into Greek and Roman, and finally the Protestant reformation, which, according to Hoene-Wronski, opened the fourth stage of human evolution. ${ }^{12}$ This stage, built on the basis of the spiritual freedom revealed in the Word, is characterized by freedom of thought and the discovery of mental or speculative creativity. It is linked with the modern scientific revolution, the aim of which was the development of science and the liberation of human minds from theology and its dogmatic interpretations. Geographical discoveries that occurred in early modernity and an increase in the affluence of Western societies have led to the broadening of the horizons of thought and the emergence of a new, secular worldview based on science, whose development could no longer be stopped by the religious opposition. At this stage of the evolution of humankind there is a break of bonds limiting further mental human development. There is a great extension of human knowledge. As a result of the scientific revolution, the image of the world inherited from Aristotle and accepted in Christianity is overthrown and replaced by a new paradigm, which Isaac Newton expressed in full form in his book Philosophiæ Naturalis Principia Mathematica (1687). In this way, mathematical natural sciences emerge and a new ideological formation, modernity, is formed.

Nevertheless, the fourth stage of evolution, which comes with the decline of the authority of the Church and with modernity, represents advancement, but at the same time a decline. Modernity, grounded in the idea of a positive self-transformation, adopts the idea of progress as one of its leading ideas. However, it understands it in a narrow sense as a scientific progress and the improvement of material conditions of life, while it dismisses religion and its moral teachings. Ethics becomes

11 Hoene-Wroński, Metapolityka, 123.

12 Ibidem, 84. 
increasingly removed from politics in both theory and social practice. ${ }^{13}$ Thus, while making so many wonderful scientific and technological advancements, modern humankind experiences at the same time numerous social problems, revolutions and wars. Because our vast technological powers have been separated from morality and even during our current postmodern period from rationality, there is a real danger that humanity will retreat to the first stage of its evolution, or even to barbarity, and annihilate itself.

\section{A Solution of Modern and Post-Modern Social Antinomy}

When he wrote his Messianisme, Hoene-Wroński did not have the abundance of the sources of information about different civilizations that we have today. Thus, his views may sound rather Eurocentric. Certainly, we can enrich his picture by tracing the evolution of moral concepts and their impact on societies in India, China and in the Muslim world. ${ }^{14}$ These developments do not need to be parallel to each other because each civilization depends on its own traditions and values, and develops at its own pace. One can also argue that the first stage of evolution which Hoene-Wroński describes is not the first, but rather represents some form of regress or even degeneration, and that the idea of moral self-improvement should be sought much earlier than the times when the first great codes of laws were established..$^{15}$ However, apart from these objections, Hoene-Wroński's thesis that in the course of history our moral and intellectual evolution is taking place, but at the same time, as a result of the demoralization of societies, the achievements of human evolution may be lost, and we may lose many hundred or even thousand

13 The thinkers who challenged the Classical Tradition of linking politics with ethics were the early modern thinkers Machiavelli and Hobbes. See W. Julian Korab-Karpowicz, On the History of Political Philosophy: Great Political Thinkers from Thucydides to Locke (New York: Routledge, 2016), 115-139 and 158-183.

14 The idea of internal moral improvement can also be found in Brahmanism, Buddhism and Jainism, as well as in Taoism and Sufism. See Harold Coward, The Perfectibility of Human Nature in Eastern and Western Thought (New York: SUNY, 2008).

15 Hoene-Wroński mentions the Vedas next to the Decalogue as an example of God's early legislation, but the Vedas are not laws but hymns and utterances about reality. The Vedic knowledge was revealed (śruti) to the sages (rsi) and has been passed down by Brahmins, or priests, from generation to generation. The age of the Vedas is estimated at around 3,500 years, so they are about 1000 years older than the laws of Manu. See Shashiprabha Kumar, ed., Veda as Word (New Delhi: D.K. Printworld, 2006). 
years of civilizational development, is worth considering, as well as his conclusions.

The next, fifth stage of human evolution, which Hoene-Wroński believed had already begun during his times, is the age of revolutionary changes and severe conflicts. All sorts of conflicting issues that potentially divide humanity arise: religious, economic, political, civilizational; and they are often presented in a rigid, ideological form and defended furiously by opposing camps. This is the current stage of the most scientifically and technologically developed humankind. It comes with the forgetfulness of who we really are, ${ }^{16}$ weakening of our religion, and the erosion of our morals. Observing our today's world, one can come to the conclusion that humanity is still in the fifth, revolutionary and at the same time critical stage of its evolution. The characteristic features of this stage are constant revolutionary change and ideological conflict. The issues that divide human beings are often presented in a rigid, dogmatic form and defended furiously by hostile camps, one of which can be described as revolutionary and the other as conservative. As a result, ideologically motivated quarrel and excessive violence become everyday life. Everyone fights everyone, not just for power or for wealth, but for beliefs and particularly for the ultimate superiority of one's own belief. Lack of mutual trust is manifested in both internal and external politics, and its expression is an armament race, unheard of in history. The consequences of this are two major world wars, a danger of a third one, and numerous smaller conflicts. Paradoxically, this is the stage of humanity that is scientifically developed, and thus not primitive and dependent on changing moods, but intellectually advanced and able to think rationally. Involvement in everyday politics and the pursuit of material goods seem to absorb all humanity and exhaust our life energies. Is there a way out?

The critical stage of human development has a creative element. The rapid change and constant violence around us, as well as unresolved crises, make us reflect on our lives and stimulate critical thinking. We can solve the social antinomy in the form of claims that pretend to be equally rational but lead to contradictory results and to endless ideological conflict between people in its various forms, or, in the case of the impossibility of solving it, allow for the possible destruction of humankind. The solution of social antinomy, which will decide human fate, is the goal of the fifth stage of evolution. Hoene-Wroński believes that to get out of the global crisis, to repair the world condition, and thus to save

16 A good expression of this state of humanity is Heidegger's philosophy, based on his key concept of being's forgetfulness. See Martin Heidegger, Being and Time, trans. John Macqurrie and Edward Robinson (Oxford: Basil Blackwell, 1978) and W. Julian Korab-Karpowicz, The Presocratics in the Thought of Martin Heidegger (Frankfurt: Peter Lang, 2016), 219-237. 
ourselves from self-destruction, we must, first of all, recognize our true human identity and our destiny as humankind. Power is not the proper goal. ${ }^{17}$ The true end is not for any particular nation, religion, ideology, or political or economic system to overcome all the rest and affirm its unchallenged world domination. We have a higher task to be completed. It is on us that the evolution of the universe depends. We are vehicles of further evolution. In this phase, evolution is no longer related merely to the transformation of matter or the biological improvement of bodies, but proceeds through the development of our minds, as is expressed in our scientific and technological achievements, the effects of which we can see every day. However, the expansion of scientific knowledge is not enough if ethics is lacking, and if our consciousness declines to the level of "physical ego" as in the first stage of our evolution. To continue with our evolution, we need then to be spiritually transformed. Human beings must recognize the futility and extreme danger of today's political struggles and rediscover their true goal. They must be helped by philosophy to "discover the absolute good and the absolute truth" so that they can "fulfill their final destiny on Earth." 18 Hence, to bring "absolute Truth" and "absolute Goodness" together, as Hoene-Wroński writes, or in my words, to pursue both intellectual and moral perfection, by the way of self-transformation, is to put humanity back on the right track. The precondition for this is, as I advise in my Tractatus Politico-Philosophicus, "to depart from a world torn apart by conflict and proceed by the way of cooperation." 19

\section{Evolutionary and Absolute Consciousness}

To come out of our current critical human condition and to foster human advancement, it is necessary to reveal to humankind its highest goal, which is moral and intellectual perfection. This can be achieved through the synthesis of love and wisdom, feeling and thought, faith and reason, religion and science, tradition and innovation. The result of this synthesis, in relation to society, is social harmony and beauty. Thus, we come to the sixth stage of human evolution. It is based on the connection based the pursuit of absolute good with the search for absolute truth.

17 Hoene-Wroński view of politics is just opposite to that of the very influential twentieth-century international political theorist Hans Morgenthau, for whom: "International politics, like all politics is a struggle for power." See Hans J. Morgenthau, Politics among Nations: The Struggle for Power and Peace, 2nd ed. (New York: Knopf, 1956), 25.

18 Hoene-Wroński, Metapolityka, 90-91.

19 W. Julian Korab-Karpowicz, Tractatus Politico-Philosophicus, New Directions for the Future Development of Humankind (New York: Routledge, 2017), 4. 
It begins a new epoch in the history of humanity, which I call evolutionity, and is characterized by what I describe here as evolutionary creativity. It involves the recognition in us of inner creative powers, that is, the possibility of our self-creation by the help of practical and speculative reason..$^{20}$ They can serve us for our moral and intellectual improvement. Practical reason gives us an internal directive related to a sense of duty, or more broadly, of righteousness or what is right, the directive, which is independent of any external law and leads us to moral goodness. Speculative reason, in turn, gives an internal cognitive certainty, which is independent of experience and leads us to truth..$^{21}$ Through the development of these internal powers, a spiritual transformation and further evolution of humanity are carried out. Reaching evolutionary consciousness, people understand that through their internalization, or internal moral and intellectual development, they are progressively released from their physical and biological conditions, and thus become agents of their own evolution, which is also the next phase of the universe's evolution. Realizing their capabilities and their evolutionary role in the universe, they enter a new age, the evolutionary epoch or evolutionity, ${ }^{22}$ which replaces the current revolutionary epochs of modernity and postmodernity.

The further evolution of humanity is connected with the use of science and technology for our bodily-mental development - intelligence, health, longevity - as proposed by the transhumanists, as well as our cultural development aimed at moral and intellectual perfection. Only such a holistic development - physical, biological, moral and intellectual - can be justified and regarded as fully balanced. High intelligence and bodily fitness are not enough. If intelligent individuals use their minds to serve the material aspects of our existence and at the same time do not adequately develop their moral sensitivities, they will perform evil acts, and these will be the more harmful to others the more these individuals are equipped with the power of the latest achievements of science and technology. For our further human development and possible departure into space, and our future life on other planets, humanity must enter the path of moral goodness. In practice this means everyday kindness, mutual respect, good-heartedness, harmonious cooperation, common friendliness and human brotherhood. Today, just like in the past, it is difficult to fully imagine the future and the great achievements human beings are still capable of. For our further evolution, however, we need not only to understand our great task, but also to engage in

20 Hoene-Wroński, Metapolityka, 285.

21 Hoene-Wroński, Ibidem 366-367.

22 The notion of evolutionity has been introduced in my Tractatus Politico-Philosophicus. It is not Hoene-Wroński's concept. However, I believe it is useful to interpret his ideas. 
practical cooperation. The progress of humanity requires both external and internal peace, and appropriate material and social conditions. Their achievement depends on the harmonious cooperation of individuals, groups, societies and countries at various levels.

The last, seventh stage of the evolution of humanity, which we can describe as absolute creativity, is the culmination of human development. This means that humanity now comes to "absolute goodness" and to "absolute truth," achieves perfection, and thus realizes the postulate of Christ: "Be so perfect as your heavenly Father is perfect" (Matthew 5:48). Although Hoene-Wroński left us only a small description of this stage, ${ }^{23}$ one can assume that the evolution of humanity achieves its purpose only when it is fully reborn spiritually and embodies what is absolute. Already at the sixth stage of its development, human beings partially discover the inner essence of the Absolute as the identity of knowledge and being. Hence, as quantum theory has already proven, in the process of cognition they go beyond the dichotomy of the subject and the object or of the knower and the known. ${ }^{24}$ Moving in that direction humanity achieves a state of supreme consciousness, which is absolute consciousness. Is it the union of the individual consciousness with the highest consciousness, of the human being with God? Is this the unlimited power of creation which is now granted to humankind? Does it mean that human beings exceed now their bodily and mental limitations, and thus come to the end of their evolution? Because the possibilities of what is absolute are unlimited, it is impossible to imagine them. ${ }^{25}$ The full human selfrealization means their implementation. Our thought has no limits. If we were to show our ancestors of a thousand years ago, a movie showing today's modern cities, they would stand in awe of our achievements. So, in order to recognize our full potential and to understand who we can still become as humans, we must continue to exist and to develop further. We must resolve today's conflicts, put aside the threat of wars, remove media manipulation, improve living conditions, embrace natural and

23 Hoene-Wroński, Metapolityka, 79.

24 There is subjectivity in objectivity. While it is not apparent in classical Newtonian physics, which, as Heisenberg describes, "can be considered as that idealization in which we speak about the world as completely separated from ourselves," it becomes evident at the subatomic level, investigated in quantum theory, where the observed electrons do not have properties independent from the mind of the observer. See Werner Heisenberg, Physics and Philosophy: The Revolution in Modern Science, introd. by F.S.C. Northrop (New York: Prometheus, 1985), 106.

25 The Absolute exists by itself, that is unconditionally, and is a higher reality than physical or mental. The inner essence of the Absolute cannot be fully delimited, but can be understood through the act of creation and our creative acts, which means that as we evolve further the more is revealed to us. See Jerzy Braun, Zarys filozofii Hoene Wrońskiego (Warszawa: OKML 2006), 271. 
spiritual beauty, and develop further our bodily and mental capabilities. But above all, we must engage consciously in moral and intellectual perfection. It fully depends on ourselves, on the cultural environment that we create and on the quality of our thoughts and ideas, who we will be in the future, and whether we will realize our human destiny.

\section{Human Evolution and the New Science}

Many theories of human evolution can be received with reservations. They can be criticized because they depict the nature of social change as permanent and irreversible, present us with linear or cyclical concepts of history, or present later times as more developed than earlier periods. However, these criticisms do not apply to the concept of human evolution by Hoene-Wroński. We will not find in his writings, the predetermined logic of history, as it is present in Hegel or Marx; there is also no fatalism of the recurring historical cycles as in Indian philosophy. ${ }^{26} \mathrm{He}$ sees world history a struggle for the elevation of man, but the result of this fight is neither known nor predetermined. He emphasizes the importance of freedom, as well as of the development of consciousness in the course of human evolution. ${ }^{27}$ His descriptions about human nature, and in particular his emphasis on our self-creation, as a trait differentiating us from other animals, are convincing. In the physical aspects of our existence, we remain under the influence of gravity and other physical forces; in biological aspects, we are still like other animals that need to breathe, eat, rest and sleep; however, in cultural aspects, in our behavior and social relations with other people, and in our personal development, everything depends on our social environment and our own decisions, i.e. on our self-creativity, and our lives are not determined in any way. Last but not least, his case of human evolution is supported by the development of the new science: by its fresh, hitherto unthought-of discoveries and novel perspectives that it opens for humankind.

26 Cycles are periods of time in which phenomena recur. In historical cycles, the concept of which we find in ancient India, Babylon and Greece, instead of progressive development, the repetitiveness of history is emphasized. Their fatalism is connected with the fact that humanity is growing in order to fall and start another period of growth from the very beginning.

27 With each stage of the evolution of humankind as presented by Hoene-Wroński, a specific state of consciousness can be linked. These states of consciousness can refer to a single person (some persons may be more advanced than others and be in a sense ahead of their times) or the whole society. These are, as I suggest here: physical or bodily awareness, moral awareness, awareness of religious feeling, awareness of rational cognition, critical consciousness, evolutionary or creative consciousness, absolute consciousness. 
According to classical Newtonian science, the natural world is deterministic and predictable. This picture has in turn determined how human phenomena are studied. Beginning with Thomas Hobbes, who, following the scientific model of his epoch, considered the universe as nothing but body in motion and studied phenomena by applying the reductionist method, social scientists have tried to describe human beings as if they were living machines, reduce complex phenomena to their parts, and subject social life to deterministic laws. But in the meantime, physics has changed. In the twentieth century, scientists became aware that their basic concepts and their way of thinking were inadequate to describe subatomic phenomena. They have discovered that at the subatomic level, determinism no longer applies and the character of occurrences is probabilistic. This has led to profound changes in their concepts of space, time, matter, and cause and effect, and to a new vision of reality, which can be described as the new science..$^{28}$

New scientific theories, especially quantum theory, have shown that our reality, even the physical one, is far more complex than we had earlier imagined. They have brought important revisions of our earlier conceptions of the universe and our relations to it. They depict a much more sophisticated natural environment than that which can be described by the notions of objectivity and of cause and effect. There is now growing interest in applying the discoveries of the new science to social sciences. The evidence for this could be, for example, the recent work of Alexander Wendt, Quantum Mind and Social Science. ${ }^{29}$ However, as Werner Heisenberg, a Nobel Prize winning physicist, noted some time ago, we should not apply forcefully "scientific concepts in domains where they do not belong"..$^{30}$ It is mistaken to believe that we can build a social science with the help of formal models used in quantum theory and calculate utilities by using new formulas. To do so would be an attempt to interpret discoveries of the new science in the spirit of an outdated early modern philosophy. Therefore, instead of trying to relate new scientific theories directly to social phenomena, we should let them help us to overcome the narrow materialistic and deterministic interpretations

28 Books that introduce us to the new science appear regularly. See Fritjof Capra, The Turning Point: Science, Society, and the Rising Culture (New York: Bantham Books, 1983); Margaret J. Whaetley, Leadership and the New Science: Learning about Organization from an Orderly Universe (San Francisco: Berrett-Kochler, 1994); Roger Penrose, The Road to Reality: A Complete Guide to the Laws of the Universe (New York: Vintage Books, 2004); Lawrence M. Krauss, The Universe from Nothing (New York: Simon \& Schuster, 2012); Frank Wilczek, A Beautiful Question: Finding Nature's Deep Design (New York: Penguin, 2016).

29 Alexander Wendt, Quantum Mind and Social Science: Unifying Physical and Social Ontology (Cambridge: Cambridge UP, 2015).

30 Heisenberg, Physics and Philosophy, 199. 
of reality derived from Newtonian physics that still largely prevail over our minds. The insights derived from the new science should guide us to a new vision of politics and society that is appropriate to a new evolutionary epoch.

\section{Evolutionity and the New Politics}

As Hoene-Wroński pointed out in his writings, human reality is principally self-created. By discovering new ideas in physics, we can better understand physical reality, but we cannot change it; by discovering new ideas in philosophy, theology or politics, we can not only understand but also change human lives. By creating culture - our artificial material, social, spiritual environment - we transcend the limitations associated with our original, natural animal endowment. We are not subject to any determinism. We proceed beyond mere obedience to biological drives and discover freedom. By being free, we can self-create and transform ourselves. The character of any people depends to a large extent on their consciously and purposely created material, moral and intellectual environment, that is on our education, beliefs, ideals and traditions. But the culture, which we create, can be adopted and developed for both constructive and destructive goals. We have the ability to build and to destroy. Therefore, what we will make of our lives largely depends on our choices. Within the universe as we know it, we represent the pinnacle of evolution. This is reflected in our ability to think, invent things, and plan ahead, and in our capacity for ethical reflection. However, we are not complete or perfect beings. At present, we realize only a tiny fraction of our human potentialities. ${ }^{31}$ There is a huge difference between our technological abilities and our moral growth. Thus, as we become more aware of ourselves, human evolution becomes a conscious evolution, a self-transforming process. It is an enormous task, which requires that human beings cooperate with each other for its completion.

The new politics is based on the awareness of human identity and on the role of human beings in the evolutionary process. ${ }^{32}$ With the new politics, a new age of humanity begins. "It is evolutionity or the evolutionary epoch which replaces modernity and postmodernity" (8.79). While modernity was inspired by the mechanistic, materialistic and deterministic view of the universe emerging from Newtonian physics and tried to apply this view to living organisms and social phenomena, and postmo-

31 Huxley, Evolutionary Humanism, 224.

32 For a more detailed exposition of the new politics, see Korab-Karpowicz, Tractatus Politico-Philosphicus, 12-19. Numbers following quotations refer to numbered paragraphs of the Tractatus. 
dernity has been characterized by unsolved problems related to globalization, political instability, and a regress to irrationality, evolutionity is inspired by the idea of human evolution, and by the organic and holistic worldview emerging from the new science. It is not revolutionary, like most modern and postmodern intellectual and political movements, but evolutionary. It is not against traditions, but rather appreciates their value and tries to build on them. It does not want to undermine traditional religious beliefs, but rather seeks to uncover what is truly valuable in them - their spirituality. Particularly it revitalizes the classical rationality. This rational tradition, which goes back to the beginning of Western philosophy, is at its core an evolutionary one. It involves thinking and speaking meaningfully about values. It is expressed in politics aimed at a good life. A good life is not only "the wealth or material prosperity of human beings, but also their spiritual (moral and intellectual) development" (1.21). By turning itself to reason and virtue, overcoming postmodernity, transcending the old divisions of West/East, object/subject, left/ right, and embracing a comprehensive and evolutionary view of reality, the new politics aims at a good life for the whole of humankind.

\section{Bibliography}

Braun, Jerzy. Zarys filozofii Hoene Wrońskiego. Warszawa: OKML, 2006.

Capra, Fritjof. The Turning Point: Science, Society, and the Rising Culture. New York: Bantham Books, 1983.

Carneiro, Robert L., ed. The Evolution of Society: Selections from Herbert Spencer's Principles of Sociology. Chicago: The University of Chicago Press, 1967.

Chardin, Teilhard de. The Phenomenon of Man. New York: Herper, 2008.

Coward, Harold. The Perfectibility of Human Nature in Eastern and Western Thought. New York: SUNY, 2008.

Heidegger, Martin. Being and Time. Trans. by John Macqurrie and Edward Robinson. Oxford: Basil Blackwell, 1978.

Heisenberg, Werner. Physics and Philosophy: The Revolution in Modern Science. Introduction by F.S.C. Northrop. New York: Prometheus, 1985.

Heller, Michał. Nowa fizyka i nowa teologia. Kraków: Copernicus Center Press, 2014.

Hoene-Wroński, Józef. Metapolityka. Transl. from French by J. Jankowski. Warszawa: Gebethner-Wolff, 1923.

Hoene-Wroński, Josef M. Le Sphinx. Charleston, NC: Nabu Press, 2011.

Hoene-Wroński, Josef M. Messianisme, Union Finale de La Philosophie Et de La Religion Constituant La Philosophie Absolue. Maurepass: Hachette LivreBnf, 2013.

Hoene-Wroński, Josef M. Propedeutique Messianique: Elements de La Philosophie Absolue. Maurepass: Hachette Livre-Bnf, 2015. 
Huxley, Julian. Evolutionary Humanism. New York: Prometheus, 1992.

Korab-Karpowicz, W. Julian. Tractatus Politico-Philosophicus, New Directions for the Future Development of Humankind. New York: Routledge, 2017.

Korab-Karpowicz, W. Julian. On the History of Political Philosophy: Great Political Thinkers from Thucydides to Locke. New York: Routledge, 2016.

Korab-Karpowicz, W. Julian. The Presocratics in the Thought of Martin Heidegger. Frankfurt: Peter Lang, 2016.

Krauss, Lawrence M. The Universe from Nothing. New York: Simon \& Schuster, 2012.

Kumar, Shashiprabha, ed. Veda as Word. New Delhi: D.K. Printworld, 2006.

Morgenthau, Hans J. Politics among Nations: The Struggle for Power and Peace, 2nd ed. New York: Knopf, 1956.

Penrose, Roger. The Road to Reality: A Complete Guide to the Laws of the Universe. New York: Vintage Books, 2004.

Pinker, Steven. The Better Angels of Our Nature: Why Violence Has Declined. New York: Penguin, 2011.

Wendt, Alexander. Quantum Mind and Social Science: Unifying Physical and Social Ontology. Cambridge: Cambridge UP, 2015.

Whaetley, Margaret J. Leadership and the New Science: Learning about Organization from an Orderly Universe. San Francisco: Berrett-Kochler, 1994.

Wilczek, Frank. A Beautiful Question: Finding Nature's Deep Design. New York: Penguin, 2016.

\section{Summary}

In this article, I present the concept of human evolution by Józef Hoene-Wroński. I believe that his ideas are still an unexplored resource which can lead us to the better understanding of the evolution of humanity and of our human destiny. Hoene-Wroński has boldly challenged the deterministic picture of the world emerging from modern science and has derived human evolution from the moral and rational development of human beings. I follow closely his discussion of human evolution and describe its seven stages. Further, I argue that the case of human evolution is strongly supported by new scientific theories, especially by quantum theory and the novel perspectives that it opens for humankind. I end my article with the conclusion that the insights on human evolution derived from the Hoene-Wroński's writings and from new scientific theories can guide us to the new politics based on the awareness of true human identity - the politics, which can overcome old divisions among humankind and conflicts derived from them. Ultimately, they can initiate evolutionity - the new evolutionary epoch, which will replace modernity and postmodernity.

Keywords: human evolution, modernity, postmodernity, evolutionity, moral and intellectual development, Hoene-Wroński, new politics 


\section{Streszczenie}

\section{Ewolucyjność - Nowa epoka ludzkości: koncepcja ludzkiej ewolucji według Hoene-Wrońskiego}

W artykule przedstawiam koncepcję ewolucji ludzkości Józefa Hoene-Wrońskiego. Staram się pokazać, że idee autora Metapolityki są dla nas nadal aktualne i mogą nam pomóc lepiej zrozumieć ludzką ewolucję i nasze przeznaczenie. W swoich pismach Hoene-Wroński odważnie podważył wyłaniający się z nauki nowożytnej deterministyczny obraz świata oraz wyprowadził ludzką ewolucję z rozwoju moralnego i rozumowego człowieka. Analizuję siedem etapów ewolucji, jakie przedstawia. Twierdzę, że jego koncepcja ewolucji ludzkości znajduje poparcie w nowych teoriach naukowych, zwłaszcza w teorii kwantów oraz nowych perspektywach myśli, które otwiera. Kończę mój artykuł wnioskiem, że idee związane z ewolucją ludzkości, jakie wyłaniają się z pism Hoene-Wrońskiego i nowych teorii naukowych, mogą doprowadzić nas do koncepcji nowej polityki, opartej na świadomości prawdziwej ludzkiej tożsamości - polityki, która może przezwyciężyć dawne podziały między ludźmi i konflikty z nich się wywodzące. Mogą one inicjować ewolucyjność, czyli nową epokę ewolucyjną, która zastąpi moderność (nowoczesność) i postmoderność (ponowoczesność).

Słowa kluczowe: ewolucja ludzkości, moderność, postmoderność, ewolucyjność, rozwój moralny i umysłowy, Hoene-Wroński, nowa polityka 